Article

\title{
Synthesis, Antibacterial, and Anti HepG2 Cell Line Human Hepatocyte Carcinoma Activity of Some New Potentially Benzimidazole-5-(Aryldiazenyl)Thiazole Derivatives
}

\author{
Mohamed E. Khalifa ${ }^{1, *(D)}$, Adil A. Gobouri ${ }^{1}$, Fahad M. Kabli ${ }^{1}$, Tarik A. Altalhi ${ }^{1}$, \\ Abdulraheem S. A. Almalki ${ }^{1}$ and Mahmoud A. Mohamed ${ }^{2}$ \\ 1 Department of Chemistry, faculty of Science, Taif University, Taif 21974, Saudi Arabia; \\ agobouri00@yahoo.com (A.A.G.); fmk_37@hotmail.com (F.M.K.); tmmba@windowslive.com (T.A.A.); \\ drasaalmalki1@gmail.com (A.S.A.A.) \\ 2 Department of Biochemistry, Faculty of Agriculture, Cairo University, Giza 12613, Egypt; \\ elcamel.mahmoud@gmail.com \\ * Correspondence: mohamedezzat200@hotmail.com; Tel.: +966-569846966
}

Received: 16 November 2018; Accepted: 9 December 2018; Published: 11 December 2018

\begin{abstract}
The paper describes the synthesis and biological evaluation of some new benzimidazole derivatives as potent clinical drugs that are useful in the treatment of some microbial infections and tumor inhibition. The starting compound 2-(bromomethyl)- $1 H$-benzimidazole (1) was prepared, and hence underwent interesting functionalization reactions to afford several series of benzimidazole-5-(aryldiazenyl)thiazole derivatives: $\mathbf{3 a - c}, \mathbf{7 a - c}$, and $\mathbf{8 a - c}$. The antibacterial activities of the synthesized compounds were evaluated by calculation of the inhibition zone diameter $(\mathrm{mm})$ and the determination of minimum inhibitory concentration $(\mu \mathrm{g} / \mathrm{mL})$ against selected pathogenic bacteria Staphylococcus aureus (Gram-positive bacteria) and Escherichia coli (Gram-negative bacteria).Noticeable efficiency was found based on in vitro screening for their antioxidant activity and cytotoxicity effect against the human liver cancer cell line (HepG2) and human hepatocyte carcinoma cells at relatively high concentrations.
\end{abstract}

Keywords: benzimidazoles; antimicrobial activity; antitumor; HepG2 cell line; pathogenic bacteria

\section{Introduction}

The promising therapeutic potential of benzimidazole derivatives could be traced back to 1944and Woolley, who speculated that benzimidazole could act similar to purines to elicit some biological responses [1]. The optimization of substituents around the benzimidazole nucleus resulted in many drugs with useful therapeutic activities such asmethyl (5-benzoyl-1H-benzimidazol-2-yl)carbamate (mebendazole) as parasitic worm infestations, (RS)-2-([3-methyl-4-(2,2,2-trifluoroethoxy)pyridin-2-yl]methylsulfinyl)-1H-benzo[d]imidazole (lansoprazole) and (RS)-6-(difluoromethoxy)-2-[(3,4-dimethoxypyridin-2-yl)methylsulfinyl]-1Hbenzo[d]imidazole (pantoprazole) as proton pump inhibitors; 1 -[(4-fluorophenyl)methyl]- $N$-[1-[2-(4methoxyphenyl)ethyl]-4-piperidyl]benzoimidazol-2-amine (astemizole) as antihistaminic[2]; triazole-thiazol derivatives as analgesic [3-6]; 2-[2-(4-chlorophenyl)-1,3-benzoxazol-5yl]propanoic acid (benoxaprofen) as anti-inflammatory [4-7]; methyl [5-(propylthio)- $1 H$ benzoimidazol-2-yl]carbamate (albendazole) as antimicrobials [8-10]; 1-(isopropylsulfonyl)-6-(1phenylprop-1-en-1-yl)-1H-benzo[d]imidazol-2-amine (enviradine) as antiviral [11,12]; antitubercular $\quad[13,14] ; \quad 4$-(1H-1,3-benzodiazol-2-yl)-1,3-thiazole(thiabendazole) as 
antihelmenthic [15-18]; picoline-imidazoles as anticonvulsant [19,20]; 4-[5-[bis(2-chloroethyl)amino]1-methylbenzimidazol-2-yl]butanoic acid (bendamustine) as anticancer [21-23]; 5-methoxy2-[(4-methoxy-3,5-dimethylpyridin-2-yl)methanesulfinyl]- $1 H$-benzimidazole (omeprazole) as antiulcer [24,25]; angiotension-II receptor antagonists [26]; 2-ethoxy-1-([4-[2-(2H-1,2,3,4-tetrazol5-yl)phenyl]phenyl]methyl)-1 $H$-1,3-benzodiazole-7-carboxylic acid (candesarten) as antihypertensive [27]; alkynyl benzimidazoles as modulators of metabotropic glutamate receptors [3,16-18,24,28-30]; and $N$-ribosyl-dimethyl benzimidazole as an axial ligand for cobalt in vitamins $[19,31,32]$.Aiming to prepare heterocyclic systems with some role in biological applications, we report in the present work the synthesis of novel derivatives of benzimidazoles by convenient methods. In vitro screening for their antimicrobial activities was determined against selected pathogenic bacteria, namely Staphylococcus aureus (Gram-positive bacteria) and Escherichia coli (Gram-negative bacteria) using inhibition zone diameter $(\mathrm{mm})$ and minimum inhibitory concentration methodologies comparing with Kanamycin and Ampicillin, respectively, as standard antibacterial agents. Their antioxidant and antitumor activities against the HepG2 human hepatocyte carcinoma cell line were also evaluated.

\section{Results}

Benzimidazoles are hybrid heterocyclic compounds that are formed from fused benzene and imidazole rings with broad industrial, biological, and clinical applications. The associated rich literature with benzimidazole moieties prompted us to synthesize new functionalized benzimidazole derivatives and study their potential as bioactive compounds, continuing our previous efforts related to the synthesis of new pharmacological compounds [33-41].

\subsection{Chemistry}

Synthesis of the starting 2-(bromomethyl)- $1 H$-benzimidazole (1) proceeded smoothly according to the reported method by the reaction of $o$-phenylenediamine with bromoacetic acid in the presence of $4 \mathrm{M}$ hydrochloric acid, as shown in Scheme 1.

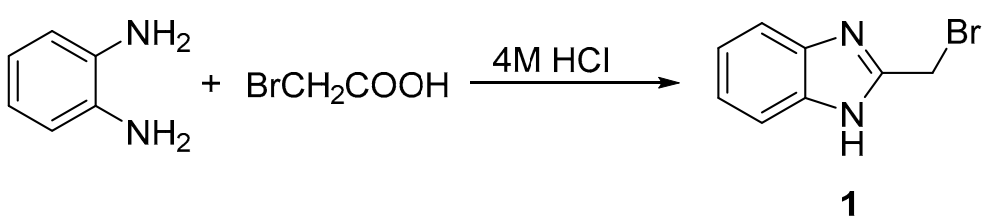

Scheme 1. Synthesis of 2-(bromomethyl)-1H-benzimidazole (1).

The IR spectrum of 2-(bromomethyl)- $1 H$-benzimidazole (1) revealed intense IR bands at $3372-3025 \mathrm{~cm}^{-1}\left(\mathrm{NH},=\mathrm{CH}\right.$ aromatic, and $-\mathrm{CH}$ aliphatic). The ${ }^{1} \mathrm{H}-\mathrm{NMR}$ spectrum displayed a singlet signal at $\delta 4.85 \mathrm{ppm}$ due to the methylene protons $\left(2 \mathrm{H}, \mathrm{CH}_{2}-\mathrm{Br}\right)$, a singlet at $\delta 10.32 \mathrm{ppm}$ due to the $\mathrm{NH}$-benzimidazole proton, and at $\delta 7.21-7.60 \mathrm{ppm}$ due to the aromatic protons. The spectral analysis was found to be in good agreement with the literature [42].

The direct condensation of 2-(bromomethyl)- $1 H$-benzimidazole (1) with 2-aminothiazole was carried out to give the $N-((1 H$-benzimidazol-2-yl)methyl)thiazol-2-amine (2) [43],which underwent diazo coupling with different aryl diazonium chorides, yielding the corresponding $\mathrm{N}$-((1H-benzimidazol-2-yl)methyl)-5-(aryldiazenyl)thiazol-2-amines (3a-c), as shown in Scheme 2. 


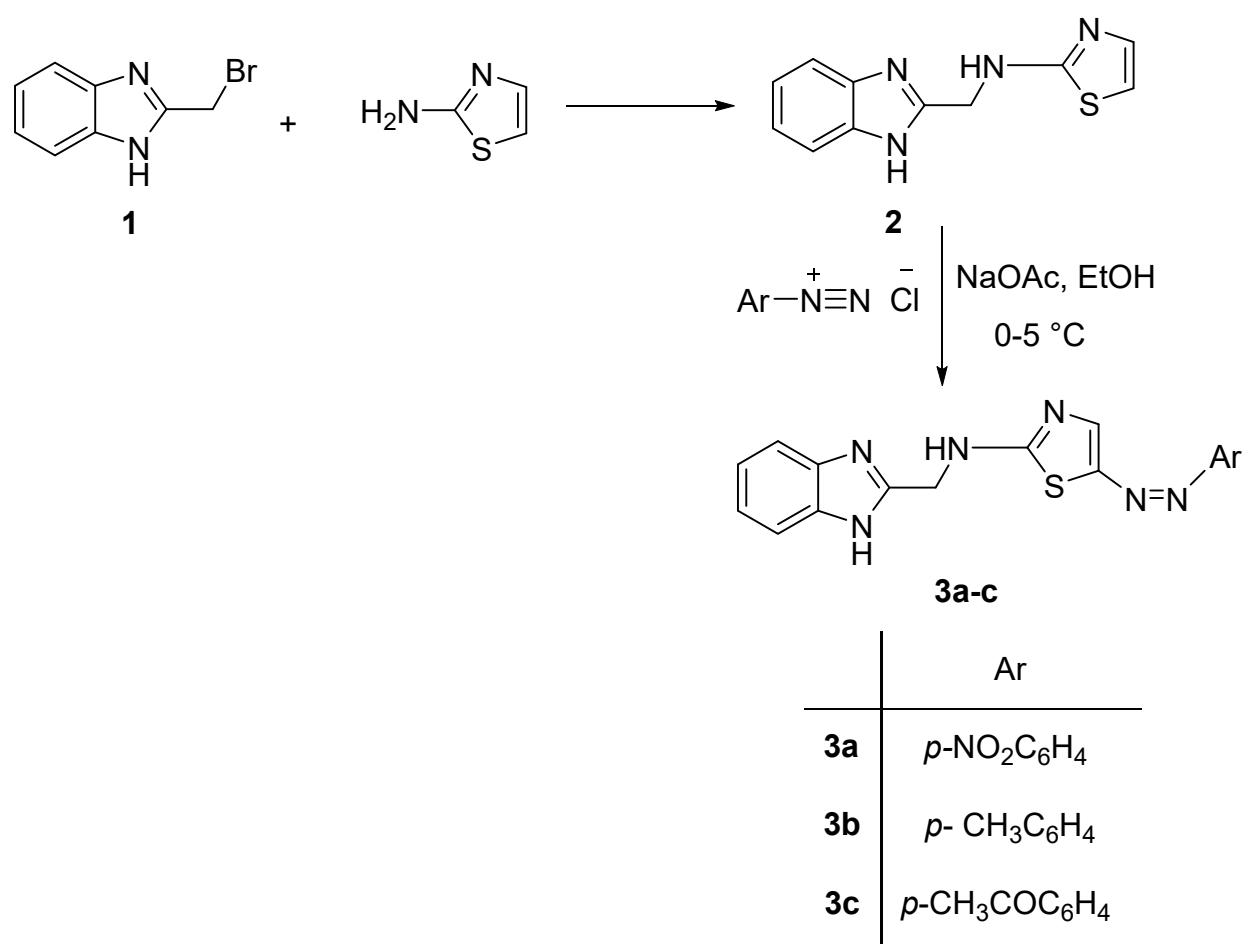

Scheme 2. Synthesis steps for the preparation of benzimidazole derivatives(3a-c).

The structures of the isolated compounds ( 2 and $3 \mathbf{a}-\mathbf{c}$ ) were secured by their spectral analysis as described in the experimental section, where a characteristic singlet signal at $\delta 6.90 \mathrm{ppm}$ due to the $\mathrm{C}_{4}$-thiazole proton was displayed.

The reaction of thiourea with $\alpha$-haloalkyl or $\alpha$-halocarbonyl compounds often proceed through the sulfur atom due to its high nucleophilicity to give thiouronium salts [44]. Whereas, conducting the reaction under acidic medium (e.g., trifluoroacetic acid) afforded the alkylthiourea compounds [45-47]. Thus, the reaction of 2-(bromomethyl)-1H-benzimidazole (1) with thiourea in acidic medium gave the previously reported derivative 1-((1H-benzimidazol-2-yl)methyl)thiourea (4) [45] through the suggested mechanism in Scheme 3. The structure of the obtained compound was secured by its spectral analysis, and was in good agreement with the literature.

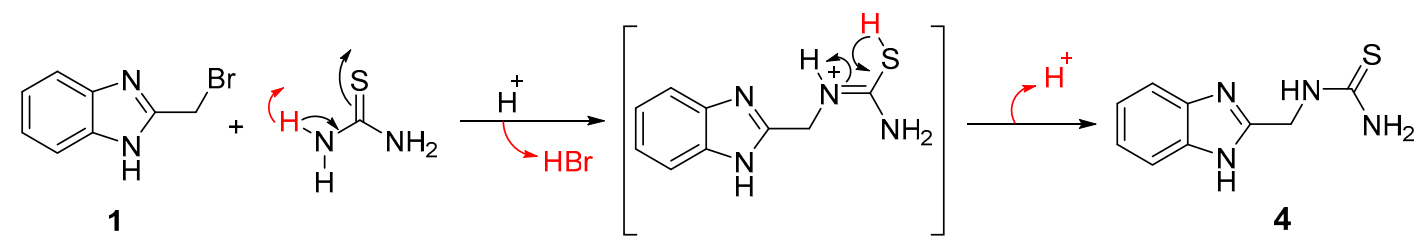

Scheme 3. Mechanism of formation of alkylthiourea benzimidazole derivative (4).

The thiourea derivative 4 was then incorporated in a set of investigations aiming at exploiting the reactivity of the thioureido moiety to build up the target compounds. Thus, 1-((1H-benzimidazol-2-yl)methyl)thiourea (4) was cyclized into the thiazole derivatives 2-(((1H-benzimidazol-2-yl)methyl)amino)thiazol-4(5H)-one (5) and $\mathrm{N}$-((1H-benzimidazol-2-yl)methyl)4-phenylthiazol-2-amine (6), by treating with $\alpha$-halocarbonyl compounds (i.e., chloroacetyl chloride and phenacyl chloride). The aminothiazolyl derivatives (5 and 6) were then allowed to couple with different aromatic diazonium chloride compounds, affording the target arylazo compounds; 2-(((1H-benzimidazol- 2-yl)methyl)imino)-5-(4-aryl)diazenyl)thiazolidin-4(5H)-one derivatives $(\mathbf{7 a}-\mathbf{c})$ and $\mathrm{N}-((1 \mathrm{H}$-benzimidazol-2-yl)methyl)-5-(4-aryl)diazenyl)-4-phenylthiazol-2-imine derivatives (8a-c) respectively, as shown in Scheme 4. 


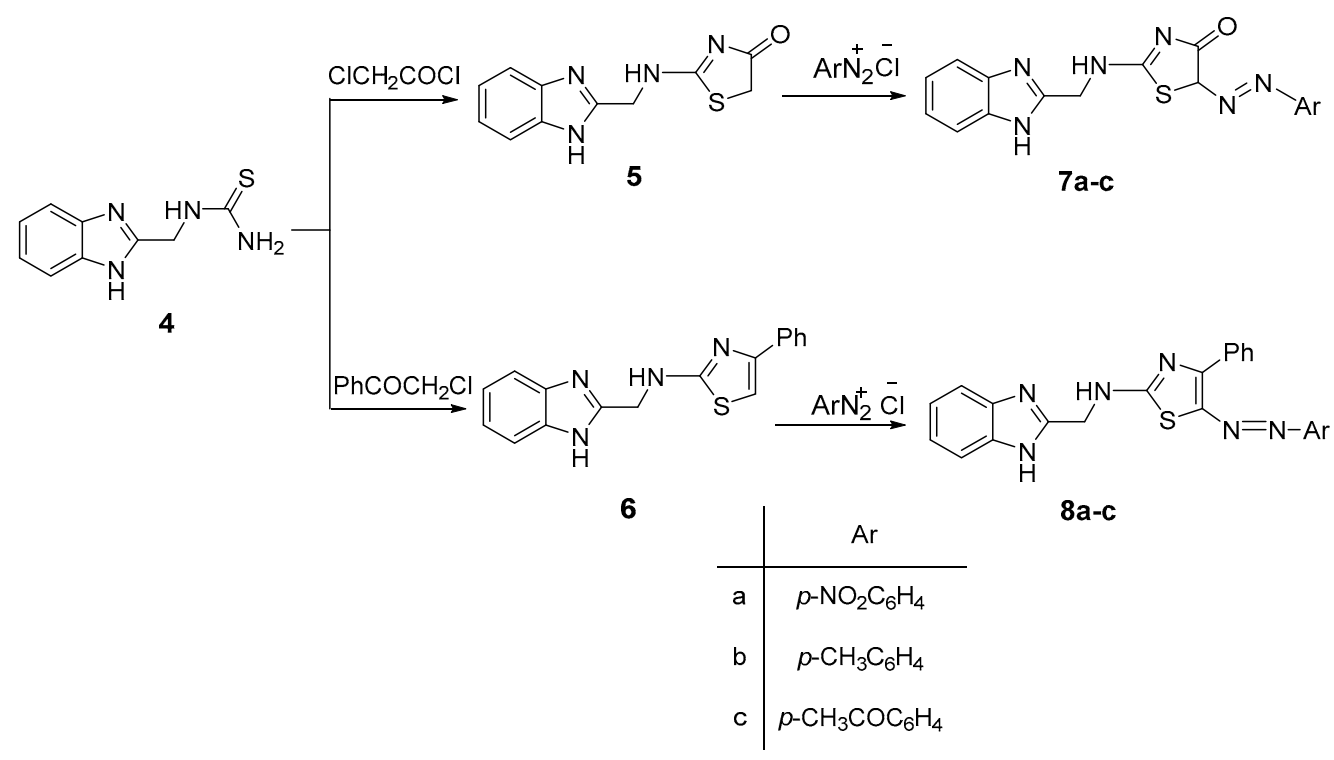

Scheme 4. Synthesis of arylazo derivatives $(7 \mathbf{a}-\mathbf{c})$ and $(\mathbf{8 a}-\mathbf{c})$. The formation of compounds $(7 \mathbf{a}-\mathbf{c}$ and $\mathbf{8 a}-\mathbf{c})$ was elucidated by their spectral analyses.

\subsection{Biological Impact of the Synthesized Compounds}

\subsubsection{Antibacterial activity}

The antibacterial activities of novel synthesized compounds $(100 \mu \mathrm{g} / \mathrm{mL}$ in DMSO), were determined in vitro by using the disc diffusion method [48] against Staphylococcus aureus (S. aureus) ATCC 25923 as Gram-positive bacteria and Escherichia coli (E. coli) ATCC 25922 as Gram-negative bacteria compared with the standard drugs Kanamycin and Ampicillin, respectively. The results of the assessments are plotted in Figure 1.

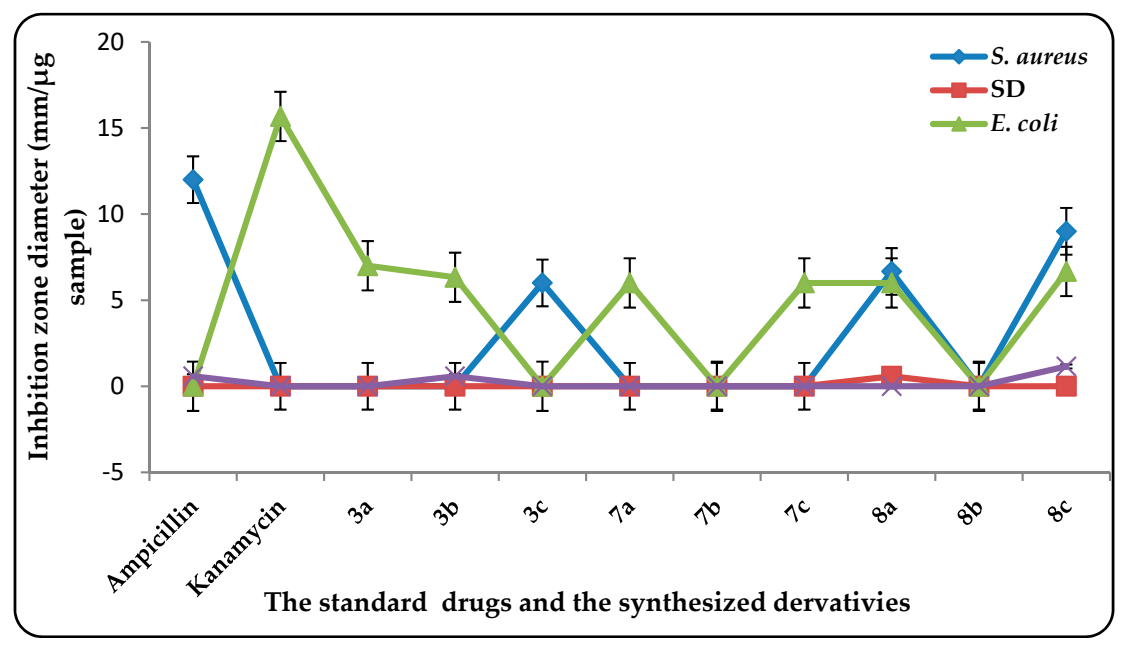

Figure 1. Antimicrobial activity of the tested benzimidazole derivatives vis-à-vis selected pathogenic bacteria strains comparing with standard drugs.

\subsubsection{Minimum Inhibitory Concentration (MIC)}

The Minimum Inhibitory Concentration for the synthesized compounds was determined using a spot-on-lawn assay [49]. The collected data are listed in Table 1. The lowest MIC value is the highest antibacterial effect against the target bacterial strain. 
Table 1. The minimum inhibitory concentration (MIC) of effective tested compounds and positive reference standards.

\begin{tabular}{|c|c|c|c|c|c|c|c|c|c|c|c|}
\hline \multirow{3}{*}{ Tested Strains } & & & \multicolumn{9}{|c|}{ MIC, $\mu \mathrm{g} / \mathrm{mL}$ (Average \pm SD) } \\
\hline & \multicolumn{2}{|c|}{ Reference Control } & & & \multicolumn{7}{|c|}{ Tested Compounds } \\
\hline & Ampicillin & Kanamycin & $3 a$ & $3 b$ & $3 c$ & $7 a$ & $7 \mathrm{~b}$ & $7 \mathrm{c}$ & $8 a$ & $8 b$ & $8 c$ \\
\hline E. coli & $2.1 \pm 0.09$ & - & - & - & $14 \pm 1.54$ & - & - & - & $16 \pm 1.05$ & - & $12 \pm 0.095$ \\
\hline S. aureus & - & $11.3 \pm 0.87$ & $32 \pm 3.95$ & $24 \pm 2.21$ & - & - & - & $27 \pm 1.23$ & $28 \pm 1.3$ & - & $21 \pm 1.64$ \\
\hline
\end{tabular}


The antibacterial study showed that some of the tested compounds exhibited variable antimicrobial activities against both bacteria Gram-negative and Gram-positive bacteria at a concentration of $100 \mu \mathrm{g} / \mathrm{mL}$. The presence of substituted electron withdrawing groups such as nitro and acetyl groups in compounds $\mathbf{3 c}, \mathbf{8} \mathbf{a}$, and $\mathbf{8 c}$ showed activities against E. coli (Gram-negative bacteria), while most of the synthesized compounds exhibited moderate activity against $S$. aureus (Gram-positive bacteria).

Compound 8c showed the highest affect against tested bacterial strains compared with the rest of the synthesized benzimidazoles under consideration due to the presence of an electron-withdrawing group (COR group) on the phenyl ring. It should be noted that the thiazolone moiety resulted in a dramatic reduction of the antibacterial efficiency (e.g., compounds $\mathbf{7 a - c}$ ).

\subsubsection{Antioxidant Potential of the Synthesized Compounds}

\section{DPPH Radical Scavenging Assay}

Antioxidant capacities for the synthesized compounds were screened using a DPPH free radical scavenging assay incorporating a metastable free radical that is capable of accepting hydrogen radicals from antioxidants in solution. The method is based upon different mechanisms to provide complementary insight into the antioxidant activity of the synthesized compounds [50]. The reaction between DPPH and antioxidants can be monitored by the decrease in the absorbance of the violet-colored free radicals. Inhibition percentages of DPPH radical by selected tested compounds were plotted in Figure 2, and the measure of drug potency in terms of half maximal effective concentration $\left(\mathrm{EC}_{50}\right)$ values were plotted in Figure 3 (i.e., the compound concentration where 50\% of its maximal effect is observed). The high antioxidant and scavenging activities of the tested compounds may be due to the resonance delocalization of the nitrogen lone pairs through the double bonds. This structure may lead to radical formation at more than one site, especially on the benzene ring attached to the electron-withdrawing groups (e.g., $3 \mathbf{a}$ and $3 \mathrm{c}$ : the highest $\mathrm{DPPH}$ value and the lowest $\mathrm{EC}_{50}$ value, respectively). This conclusion is also supported by previously reported results [51].

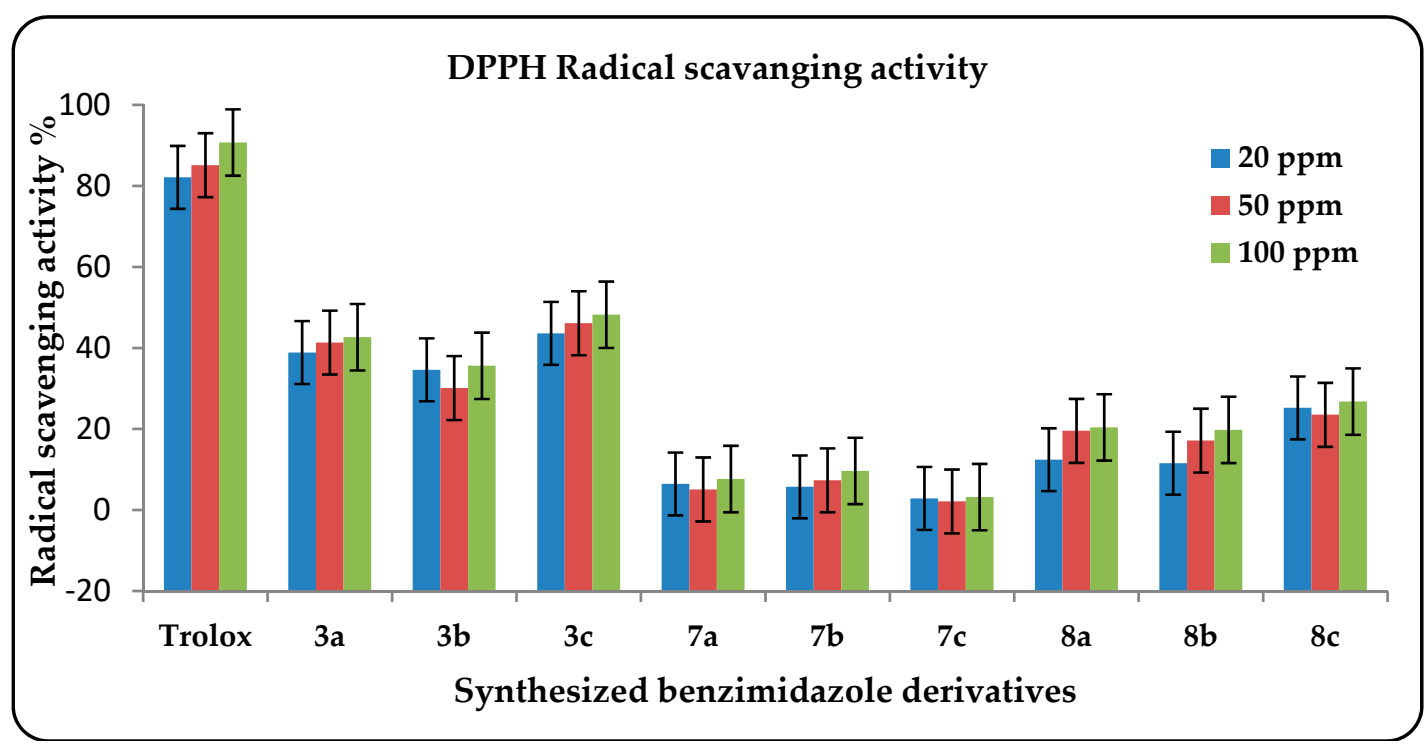

Figure 2. Inhibition percentage average results of DPPH radical by the tested synthesized benzimidazoles based on three independent experiments. 


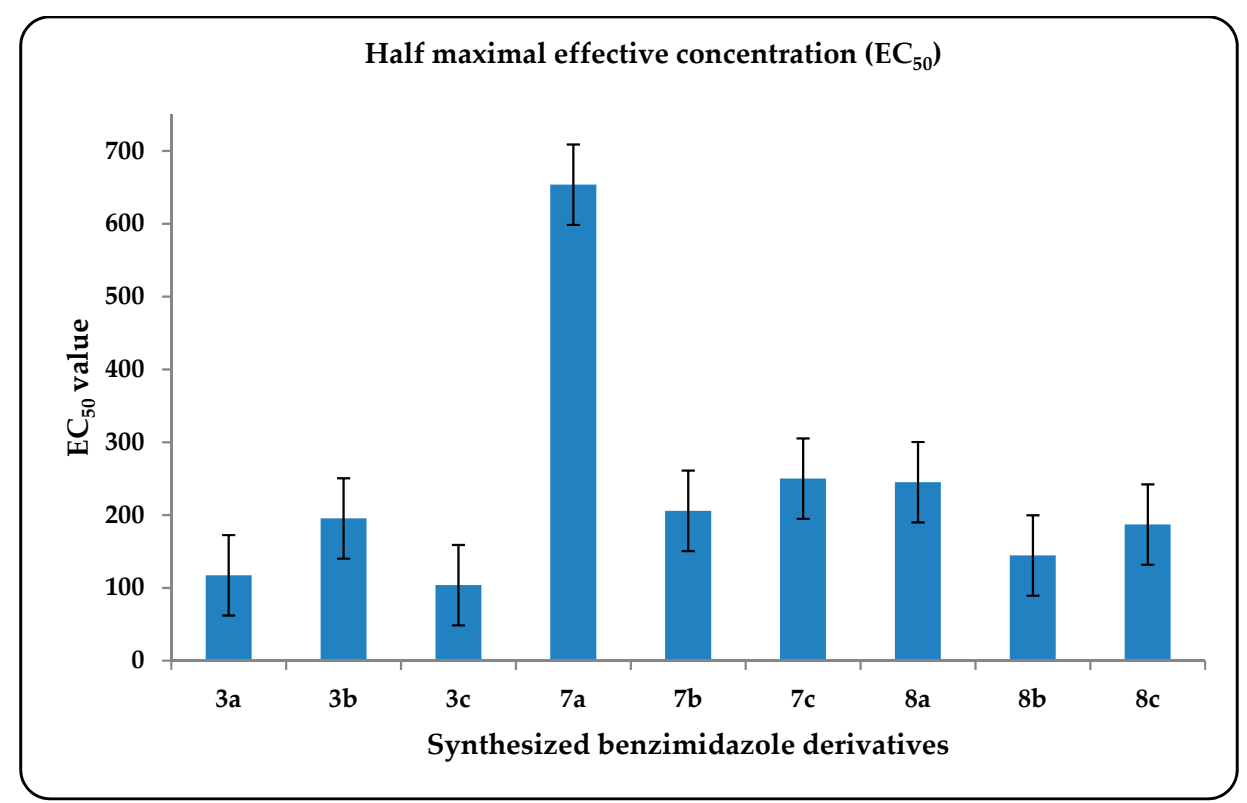

Figure 3. The average results of $\mathrm{EC}_{50}$ for the tested synthesized benzimidazoles based on three independent experiments.

2.2.4. Evaluation of Cytotoxicity Effects of Benzimidazoles and its Derivatives Against the Human Liver Cancer Cell Line (HepG2).

All of the compounds were screened in vitro for possible potential antitumor molecules against human liver cancer cell line (HepG2) and showed variable anticancer activity. The Neutral Red (NR) technique [52] was used to evaluate the cytotoxic effects of gradient concentrations $(100 \mu \mathrm{g} / \mathrm{mL}$ to $500 \mu \mathrm{g} / \mathrm{mL}$ ) of the tested compounds on the human liver (HepG2) cell line and in terms of cell viability percentage, which measured the potency of the compound in inhibiting tumor growth (Figure 4).

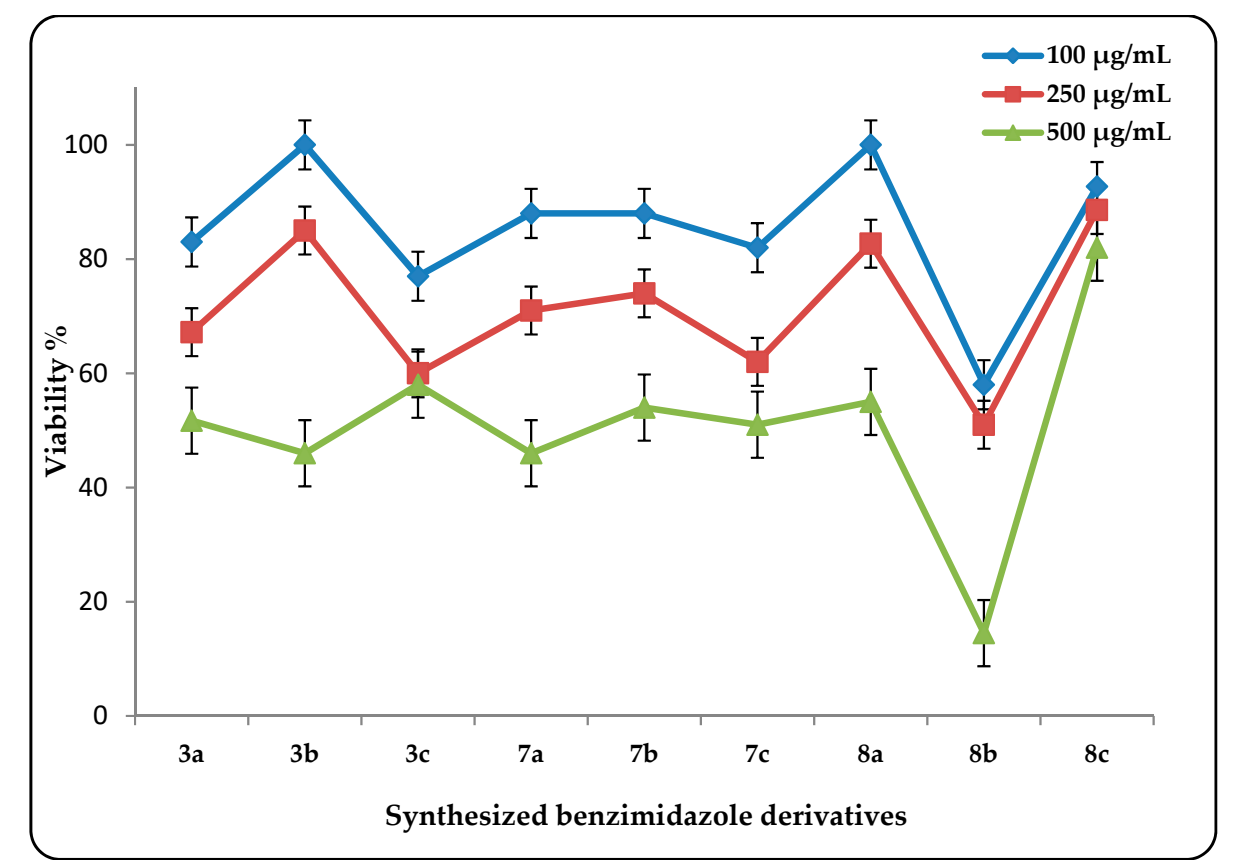

Figure 4. The viability \% of human liver cancer (HepG2) cell line treated with the synthesized benzimidazoles at $100 \mu \mathrm{g} / \mathrm{mL}, 250 \mu \mathrm{g} / \mathrm{mL}$, and $500 \mu \mathrm{g} / \mathrm{mL}$ based on three independent experiments. 
As shown in Figure 4, the tested compounds exhibited antitumor activities in different concentrations, where increasing the concentration led to less percent viability. The benzimidazole derivatives (3) and (8) in common showed higher activity than the other selected compounds that were tested. The presence of the 4-phenyl function with or without attached electron-withdrawing groups increased the antitumor activity due to their high antioxidant and free radical scavenging ability (e.g., $\mathbf{3 a}$ and $\mathbf{8 b}$ ). This also could be explained by the previously reported facts [51], and is supported by the literature [53].

\section{Materials and Methods}

\subsection{Chemical Reagents}

All of the chemical reagents that were used were of analytical grade or chemically pure and supplied by Sigma Aldrich Co., Darmstadt, Germany.

\subsection{Micro and Spectroscopic Analysis}

All of the corrected melting points are in degree centigrade and measured using a Stuart SMP20 melting point apparatus (Bibby Scientific Limited, Staffordshire, UK). The infrared spectra were recorded on a PerkinElmer Alpha platinum-ATR spectrometer; the ${ }^{1} \mathrm{H}-\mathrm{NMR}(300 \mathrm{MHz})$ and ${ }^{13} \mathrm{C}-\mathrm{NMR}$ (75 MHz) spectra were recorded on a Varian Mercury VXR-300 spectrometer (Varian Inc., Palo Alto, CA, USA) and the chemical shifts were related to that of the solvent DMSO- $d_{6}$ using tetramethylsilane (TMS) as an internal standard. MS spectra (HRMS) were acquired on TRACE GC Ultra gas chromatograph mass spectrometry, coupled with a THERMO mass spectrometer detector ISQ Single Quadrupole Mass Spectrometer (THERMO Scientific Corp., Waltham, MA, USA)and were obtained by electron ionization (EI) at $70 \mathrm{eV}$, using a spectral range of $m / z 50-1000$.All of the microanalyses and spectral analyses were performed by the Micro Analytical Centers of Taif University-Saudi Arabia (IR spectra, HRMS), Cairo University ( $\left.{ }^{1} \mathrm{H}-\mathrm{NMR},{ }^{13} \mathrm{C}-\mathrm{NMR}\right)$, and National Research Center-Egypt (Mass spectra).

\subsection{Biological Analysis}

All of the used kits for biochemical parameters were supplied by the Diagnostic Company, Maidenhead, UK. All of the chemicals that were used were supplied by Gibco ${ }^{\circledR}$ Life Technologies, Waltham, MA, USA. The biological tests were performed by the biotechnology unit, faculty of Agriculture-Cairo University, Egypt. Human transformed cell lines from liver (HepG2) were obtained from the Egyptian Company for Vaccine and Serum (VACSERA, Cairo, Egypt). The statistical package for social science (SPSS) 1999 program version (IBM, Armonk, NY, USA) was used for all of the analyses [54].

\subsubsection{Antibacterial Evaluation}

The disc diffusion procedure was used to evaluate the antibacterial activity of the synthesized compounds [53]. Uninoculated agar medium was poured in sterilized Petridishes and left for solidifying. One hundred milliliters of trypticase soy agar $+0.6 \%$ yeast extract were melted and cooled to $50{ }^{\circ} \mathrm{C}$, and then inoculated by the culture of the examined microorganism. Inoculated medium was poured over the previous layer and left to solidify at $4{ }^{\circ} \mathrm{C}$ (surface layer should be constant in volume and horizontally homogenous). Discs of Whatman No. 1 filter paper $(6.0 \mathrm{~mm}$ in diameter) were sterilized by autoclaving at $121^{\circ} \mathrm{C}$ for $15 \mathrm{~min}$. Each individual tested compound was dissolved in $10 \%$ dimethyl sulfoxide (DEMSO) with a final concentration $100 \mathrm{mg} / \mathrm{mL}$. An accurate volume $(15 \mu \mathrm{L})$ of each tested compound $(100 \mathrm{mg} / \mathrm{mL})$ was aseptically added to each disc and left to dry. Each disc was aseptically placed on the middle of an agar plate surface (in triplicate) and left at $4{ }^{\circ} \mathrm{C}$. Fifteen $\mu \mathrm{L}$ of DEMSO (10\%) was aseptically added to the disc and used as control. Then, $15 \mu \mathrm{L}$ of Kanamycin $(30 \mu \mathrm{g} / \mathrm{mL})$ was aseptically added to the disc and used as a positive standard reference for 
Gram-positive strains, and Ampicillin $(10 \mu \mathrm{g} / \mathrm{mL})$ was used for Gram-negative strains. The inhibition clear zones $(\mathrm{mm})$ were recorded in all of the samples and equal zero in no-inhibition results.

\subsubsection{Determination of Minimum Inhibitory Concentration (MIC)}

The minimum inhibitory concentration (MIC) of synthesized compounds was assayed by using a spot-on-lawn assay [49]. Cells of laboratory strains (LAB strains) were grown in de Man, Rogosa \& Sharpe MRS broth (Oxoid) supplemented with $0.5 \% \mathrm{CaCO}_{3}$ at $30{ }^{\circ} \mathrm{C}$ with shaking $(120$ strokes per min $(\mathrm{SPM})$ ) to the early stationary phase, and the initial $\mathrm{pH}$ of the medium was adjusted to $\mathrm{pH}$ 6.0. Culture fluid was obtained by removing the cells by centrifugation, and was filtered with a cellulose acetate membrane filter (pore size $0.2 \mu \mathrm{m}$; Advantec, Tokyo, Japan). The resulting sample was serially diluted twofold with MRS broth ( $\mathrm{pH} 5.0)$. Soft nutrient agar $(20 \mathrm{~mL})$ was solidified in a sterile dish $(140 \mathrm{~mm}$ by $100 \mathrm{~mm}$ ) after the addition of $60 \mu \mathrm{L}$ of an overnight culture of Listeria monocytogenes SUB635. This strain was used as an indicator in the assay, since a clearer inhibitory zone was obtained with this organism than with $B$. subtilis. After 30 min of drying, $10 \mu \mathrm{L}$ of each diluted sample was spotted onto the plate. The resulting plates were incubated at $30^{\circ} \mathrm{C}$ overnight, and the titer was defined as the reciprocal of the highest dilution $\left(2^{n}\right)$ that resulted in the inhibition of the indicator lawn. Thus, the arbitrary unit (AU) of antibacterial activity per milliliter was defined as $2^{n} \times 1000 \mu \mathrm{L} / 10 \mu \mathrm{L}$.

To examine the spectrum of activity of the purified bacteriocin against various bacterial strains, the test described above was performed with soft agar containing cells of test strains grown in a suitable medium to the early stationary phase. The abilities to inhibit a certain bacterial strain were compared by using the highest dilution that resulted in a growth inhibition zone.

\subsubsection{Assay of Cytotoxicity}

Neutral Red (NR) assay [55] was used to evaluate the cytotoxicity effects of prepared compounds. 30.000 Cells/well were plated in 96-well plates in quadruplets for each treatment. $24 \mathrm{~h}$ later, cells were washed with pre-warmed phosphate-buffered saline (PBS) and $125 \mu \mathrm{L}$ of media with an appropriate concentration of each synthesized compound. Afterwards, cells were washed with pre-warmed PBS, and $125 \mu \mathrm{L}$ of the NR reagent was added in each well. The plates were incubated at $37{ }^{\circ} \mathrm{C}$ with $5 \%$ $\mathrm{CO}_{2}$, for a further $5 \mathrm{~h}$. After incubation, plates were taken out, gently washed three times with PBS, and $100 \mu \mathrm{L}$ of NR desorb solution was added per well. Plates were protected from light and shaken on a shaker at $60 \mathrm{rpm}$ for $30 \mathrm{~min}$, followed by keeping the plates still for $5 \mathrm{~min}$. Plates were taken to a 96-well plate reader, and their absorbance was measured in each well at $540 \mathrm{~nm}$. Each value is based on means of the absorbance values acquired from the quadruplet of treatments and normalized to the mean value of untreated control and expressed as \% cell death according to the following equation (Equation (1)):

$$
\% \text { Cell death }=\frac{\mathrm{Abs}_{540} \text { treated sample }}{\mathrm{Abs}_{540} \text { untreated sample }} \times 100
$$

The data is based on three independent experiments.

\subsubsection{Antioxidant Potential}

The tested compounds were analyzed for their antioxidant potential according to the reported technique [56]. The stock solution of 1,1-diphenyl-2-picrylhydrazyl (DPPH) was prepared by dissolving $24 \mathrm{mg}$ of DPPH in $100 \mathrm{~mL}$ of methyl alcohol $(\mathrm{MeOH})$, and then stored at $20^{\circ} \mathrm{C}$ in the dark. The working solution was obtained by diluting $10 \mathrm{~mL}$ of stock solution with $45 \mathrm{~mL}$ of $\mathrm{MeOH}$, in order to obtain an absorbance of $1.1 \pm 0.1$ units at $515 \mathrm{~nm}$. A volume of $10 \mu \mathrm{L}$ of different synthesized compounds' concentrations $(20 \mu \mathrm{g} / \mathrm{mL}, 50 \mu \mathrm{g} / \mathrm{mL}$, and $100 \mu \mathrm{g} / \mathrm{mL})$ was added to $990 \mu \mathrm{L}$ of $0.094 \mathrm{mM}$ DPPH freshly working solution up to total volume of one mL. Assays were continuously monitored at $515 \mathrm{~nm}$ over a one-hour period at $25^{\circ} \mathrm{C}$. Changes in absorbance were minimal for all of the samples after $50 \mathrm{~min}$. The antioxidant abilities were expressed as $\mu \mathrm{M}$ Trolox equivalents. Each sample was analyzed 
in triplicate. The inhibition percentage of the DPPH radical by the samples was calculated according to Equation (2):

$$
\% \text { Inhibition }=\frac{[\mathrm{Ab}-\mathrm{Aa}]}{\mathrm{Ab}} \times 100
$$

where, $\mathrm{Ab}$ is the absorption of the blank sample $(\mathrm{t}=0 \mathrm{~min})$, and $\mathrm{Aa}$ is the absorption of the tested compound or standard substance solution $(\mathrm{t}=30 \mathrm{~min})$. The $\mathrm{EC}_{50}$ value is defined as the concentration of antioxidant in the reactive system that is necessary to decrease the initial DPPH concentration by $50 \%$, and is calculated from the data obtained.

\subsection{Synthesis and Structural Analysis}

\subsubsection{General Procedure for the Synthesis of 2-(Bromomethyl)-1H-Benzimidazole (1)}

The 2-bromomethyl benzimidazole (1) was prepared according to the literature procedure [48,57,58], where $O$-phenylenediamine $(2.16 \mathrm{~g}, 20 \mathrm{mmol})$ was dissolved in $30-40 \mathrm{~mL}$ of four $\mathrm{M}$ of $\mathrm{HCl}$ by heating. The bromoacetic acid $(4.16 \mathrm{~g}, 30 \mathrm{mmol})$ was added thoroughly, and then, the reaction mixture was boiled under reflux for five $h$. The mixture was neutralized with ammonia, and the solid product was filtered, washed with water, and dried. The obtained product was recrystallized from acetone to give red crystals. M.p.: $60-62{ }^{\circ} \mathrm{C}\left(59-61{ }^{\circ} \mathrm{C}\right.$ [42]), yield: $3.6 \mathrm{~g}, 86 \%$.

\subsubsection{Synthesis of $\mathrm{N}-((1 H$-Benzimidazol-2-yl)Methyl)Thiazol-2-Amine (2)}

A mixture of 2-(bromomethyl)- $1 H$-benzimidazole 1 (2.11 g, $10 \mathrm{mmol})$, 2-aminothiazole $(1 \mathrm{~g}$, $10 \mathrm{mmol})$, and potassium iodide $\mathrm{KI}(1.66 \mathrm{~g}, 10 \mathrm{mmol})$ in ethanol $(50 \mathrm{~mL})$ was heated under reflux for $6 \mathrm{~h}$. Afterwards, an aqueous solution of potassium hydroxide $\mathrm{KOH}(1.66 \mathrm{~g}, 10 \mathrm{mmol}$, in five $\mathrm{mL}$ of $\mathrm{H}_{2} \mathrm{O}$ ) was added and heating was continued for a further $2 \mathrm{~h}$. The cold reaction mixture was poured onto ice-cold water, and the precipitated solid product was filtered off, dried, and recrystallized from ethanol to give reddish brown crystals of $N$-((1H-benzimidazol-2-yl)methyl)thiazol-2-amine (2). M.p.: $>250{ }^{\circ} \mathrm{C}\left(398^{\circ} \mathrm{C}[43]\right)$, yield: $1.6 \mathrm{~g}, 69 \%$.

3.4.3. General Procedure for the Synthesis of the $N-((1 H$-Benzimidazol-2-yl)Methyl)-5(Aryldiazenyl)Thiazol-2-Amine (3a-c)

The corresponding aryl diazonium chlorides were prepared by adding cold sodium nitrite solution $\left(0.69 \mathrm{~g}, 10 \mathrm{mmol}\right.$ in $10 \mathrm{~mL}$ of $\mathrm{H}_{2} \mathrm{O}$ ) to a cold suspension of $10 \mathrm{mmol}$ of different aromatic amines (namely $p$-nitroaniline, $1.38 \mathrm{~g}$; $p$-toluidine, $1.07 \mathrm{~g}$; and $p$-aminoacetophenone, $1.35 \mathrm{~g})$ in concentrated $\mathrm{HCl}(4-6 \mathrm{~mL})$ with stirring. To a cold solution of $N$-((1H-benzimidazol-2-yl)methyl)thiazol-2-amine $2(2.3 \mathrm{~g}, 10 \mathrm{mmol})$ in ethanol $(40 \mathrm{~mL})$ and sodium acetate $(1.6 \mathrm{~g}, 20 \mathrm{mmol})$, a cold aqueous solution from the corresponding aromatic diazonium salts was added dropwise with stirring at $0-5{ }^{\circ} \mathrm{C}$ for $2 \mathrm{~h}$. The solid products obtained were filtered off, washed with water followed by cold ethanol, dried, and recrystallized from ethanol to give $N$-((1H-benzimidazol-2-yl)methyl)-5-(aryldiazenyl)thiazol-2-amine (3a-c).

N-((1H-benzimidazol-2-yl)methyl)-5-((4-nitrophenyl)diazenyl)thiazol-2-amine (3a). Brown solid, M.p.: $>250{ }^{\circ} \mathrm{C}$, Yield: $2.4 \mathrm{~g}, 63 \%$. IR: $v_{\max }=3740-2850(\mathrm{NH},=\mathrm{CH}$ aromatic, $-\mathrm{CH}$ aliphatic $), 1620(\mathrm{C}=\mathrm{N})$, 1451 $\left(\mathrm{CH}_{2}\right)$ and 1335, $1569\left(\mathrm{NO}_{2}\right) \mathrm{cm}^{-1} .{ }^{1} \mathrm{H}-\mathrm{NMR}: \delta / \mathrm{ppm}=3.51\left(\mathrm{~s}, 2 \mathrm{H}, \mathrm{CH}_{2}\right.$ aliphatic), $5.87(\mathrm{~s}, 1 \mathrm{H}$, $\mathrm{NH}), 6.95-7.65$ (m, 8H, Ar-H; s, 1H, C 4 -thiazole-H), 10.90 (s, 1H, NH-benzimidazole ring). ${ }^{13} \mathrm{C}-\mathrm{NMR}$ : $\delta / \mathrm{ppm}=43.2,115.2(2 \mathrm{C}), 123.0(2 \mathrm{C}), 123.8(2 \mathrm{C}), 126.6(2 \mathrm{C}), 134.7,138.8(2 \mathrm{C}), 140.7,141.5,147.2,147.8$, 163.2. MS $(m / z, \%): 379\left(\mathrm{M}^{+}, 100.0\right)$. HRMS calc. for $\mathrm{C}_{17} \mathrm{H}_{13} \mathrm{~N}_{7} \mathrm{O}_{2} \mathrm{~S}: 379.0851$, found: 379.0873 .

$\mathrm{N}-\left(\left(1 \mathrm{H}\right.\right.$-benzimidazol-2-yl)methyl)-5-(p-tolyldiazenyl)thiazol-2-amine (3b). Brown solid, M.p.: $>250{ }^{\circ} \mathrm{C}$, Yield: $1.8 \mathrm{~g}, 54 \%$. IR: $v_{\max }=3740-2850\left(\mathrm{NH}=\mathrm{CH}\right.$ aromatic, $-\mathrm{CH}$ aliphatic), $1620(\mathrm{C}=\mathrm{N}), 1453\left(\mathrm{CH}_{2}\right)$, and $1389\left(\mathrm{CH}_{3}\right) \mathrm{cm}^{-1} .{ }^{1} \mathrm{H}-\mathrm{NMR}: \delta / \mathrm{ppm}=2.49\left(\mathrm{~s}, 2 \mathrm{H}, \mathrm{CH}_{2}\right.$ aliphatic $), 3.40\left(\mathrm{~s}, 3 \mathrm{H}, \mathrm{CH}_{3}\right), 5.87(\mathrm{~s}, 1 \mathrm{H}$, $\mathrm{NH}), 6.92-7.64\left(\mathrm{~m}, 8 \mathrm{H}, \mathrm{Ar}-\mathrm{H} ; \mathrm{s}, 1 \mathrm{H}, \mathrm{C}_{4}\right.$-thiazole-H), 10.99 (s, 1H, NH-benzimidazole ring). ${ }^{13} \mathrm{C}-\mathrm{NMR}$ : 
$\delta / \mathrm{ppm}=21.3,43.2,115.2(2 \mathrm{C}), 123.0(2 \mathrm{C}), 125.6,128.8(2 \mathrm{C}), 129.0(2 \mathrm{C}), 138.3,138.8(2 \mathrm{C}), 140.7,141.5$, 147.2, 163.2. MS $(m / z, \%): 348\left(\mathrm{M}^{+}, 1.06\right)$. HRMS calc. for $\mathrm{C}_{18} \mathrm{H}_{16} \mathrm{~N}_{6} \mathrm{~S}: 348.1157$, found: 348.1168 .

1-(4-((2-(((1H-benzimidazol-2-yl)methyl)amino)thiazol-5-yl)diazenyl)phenyl)ethan-1-one (3c).Brown solid, M.p.: $>250{ }^{\circ} \mathrm{C}$, Yield: $1.7 \mathrm{~g}, 47 \%$. IR: $v_{\max }=3740-2850(\mathrm{NH},=\mathrm{CH}$ aromatic, $-\mathrm{CH}$ aliphatic), 1667 (CO acetyl), $1619(\mathrm{C}=\mathrm{N}), 1453\left(\mathrm{CH}_{2}\right)$, and $1388\left(\mathrm{CH}_{3}\right) \mathrm{cm}^{-1} .{ }^{1} \mathrm{H}-\mathrm{NMR}: \delta / \mathrm{ppm}=2.44\left(\mathrm{~s}, 2 \mathrm{H}, \mathrm{CH}_{2}\right.$ aliphatic), 3.43 (s, 3H, $\left.\mathrm{CH}_{3}\right), 5.87(\mathrm{~s}, 1 \mathrm{H}, \mathrm{NH}), 7.16-7.74\left(\mathrm{~m}, 8 \mathrm{H}, \mathrm{Ar}-\mathrm{H}\right.$; s, $1 \mathrm{H}, \mathrm{C}_{4}$-thiazole-H), 10.90 (s, $1 \mathrm{H}, \mathrm{NH}$-benzimidazole ring). ${ }^{13} \mathrm{C}-\mathrm{NMR}: \delta / \mathrm{ppm}=26.3,43.3,115.2(2 \mathrm{C}), 123.0(2 \mathrm{C}), 128.8(4 \mathrm{C})$, 133.1, 136.8, $138.8(2 \mathrm{C}), 140.7,141.5,147.3,163.2,197.0$. MS $(m / z, \%): 376\left(\mathrm{M}^{+}, 100.0\right)$. HRMS calc. for $\mathrm{C}_{19} \mathrm{H}_{16} \mathrm{~N}_{6}$ OS: 376.1106 , found: 376.1118 .

\subsubsection{Synthesis of 1-((1H-Benzimidazol-2-yl)Methyl)Thiourea (4)}

A mixture of 2-(bromomethyl)-1H-benzimidazole $1(2.11 \mathrm{~g}, 10 \mathrm{mmol})$ and thiourea $(1.14 \mathrm{~g}$, $15 \mathrm{mmol})$ in ethanol $(30 \mathrm{~mL})$ containing catalytic amount of trifluoroacetic acid $(0.02 \mathrm{~mL})$, was well stirred under reflux for $2 \mathrm{~h}$. The reaction mixture was allowed to cool, and the solid product that was formed was filtered off, washed with cold ethanol, dried, and recrystallized from ethanol to obtain a brown solid; M.p.: $129-130{ }^{\circ} \mathrm{C}$, Yield: 2 g, 99\%. IR: $v_{\max }=3740\left(\mathrm{NH}_{2}\right), 3251-3020(\mathrm{NH},=\mathrm{CH}$ aromatic, - $\mathrm{CH}$ aliphatic), $1601(\mathrm{C}=\mathrm{N})$ and $1485\left(\mathrm{CH}_{2}\right) \mathrm{cm}^{-1} .{ }^{1} \mathrm{H}-\mathrm{NMR}: \delta / \mathrm{ppm}=3.39\left(\mathrm{~d}, 2 \mathrm{H}, J=7.4 \mathrm{~Hz}, \mathrm{CH}_{2}\right.$ aliphatic), $5.87(\mathrm{t}, 1 \mathrm{H}, \mathrm{NH}), 7.18-7.48(\mathrm{~m}, 4 \mathrm{H}, \mathrm{Ar}-\mathrm{H}), 9.50\left(\mathrm{~s}, 2 \mathrm{H}, \mathrm{NH}_{2}\right), 10.90(\mathrm{~s}, 1 \mathrm{H}, \mathrm{NH}$-hydrazo), 11.31 (s, $1 \mathrm{H}, \mathrm{NH}$-benzimidazole ring). ${ }^{13} \mathrm{C}-\mathrm{NMR}: \delta / \mathrm{ppm}=44.7,115.2(2 \mathrm{C}), 123.0(2 \mathrm{C}), 138.8(2 \mathrm{C})$, 141.5, 182.5. MS $(m / z, \%): 206\left(\mathrm{M}^{+}, 100.0\right)$. HRMS calc. for $\mathrm{C}_{9} \mathrm{H}_{10} \mathrm{~N}_{4} \mathrm{~S}: 206.0626$, found: 206.0649 [45].

\subsubsection{Synthesis of (2-((1H-Benzimidazol-2-yl)Methyl)Amino)Thiazo-4(5H)-One (5)}

To a well stirred solution of 1-((1H-benzimidazol-2-yl)methyl)thiourea $4(2.06 \mathrm{~g}, 10 \mathrm{mmol})$ in $20 \mathrm{~mL}$ of ethanol containing $0.5 \mathrm{~mL}$ of triethylamine (TEA), a chloroacetylchloride $(1.12 \mathrm{~mL}, 10 \mathrm{mmol})$ was added over one $h$ at room temperature. The reaction mixture was then heated, and stirring was continued at $60{ }^{\circ} \mathrm{C}$ for five $\mathrm{h}$. The mixture was allowed to cool, and the solid product formed was collected, dried, and recrystallized from ethanol to yield orange crystals; M.p.: $>250{ }^{\circ} \mathrm{C}\left(284{ }^{\circ} \mathrm{C}\right.$ [59]), Yield: $1.8 \mathrm{~g}, 75 \%$.

\subsubsection{Synthesis of $N-((1 H$-Benzimidazol-2-yl)Methyl)-4-Phenylthiazol-2-Amine (6)}

A mixture of 1-((1H-benzimidazol-2-yl)methyl)thiourea $4(2.06 \mathrm{~g}, 10 \mathrm{mmol})$ in $20 \mathrm{~mL}$ of ethanol containing a few drops of piperidine, and phenacylchloride $(1.54 \mathrm{~g}, 10 \mathrm{mmol})$ was allowed to stir under reflux for six $\mathrm{h}$. The red dish brown solid product formed was collected, washed from methanol, dried, and recrystallized from ethanol; M.p.: $219-220{ }^{\circ} \mathrm{C}$, Yield: $2.7 \mathrm{~g}, 88 \%$. IR: $v_{\max }=3366-2950(\mathrm{NH}$, $=\mathrm{CH}$ aromatic, $-\mathrm{CH}$ aliphatic), $1629(\mathrm{C}=\mathrm{N})$, and $1444\left(\mathrm{CH}_{2}\right) \mathrm{cm}^{-1} .{ }^{1} \mathrm{H}-\mathrm{NMR}: \delta / \mathrm{ppm}=2.49(\mathrm{~s}, 2 \mathrm{H}$, $\mathrm{CH}_{2}$ aliphatic), $5.32(\mathrm{~s}, 1 \mathrm{H}, \mathrm{NH}), 7.30-7.64(\mathrm{~m}, 9 \mathrm{H}, \mathrm{Ar}-\mathrm{H}), 7.90(\mathrm{~s}, 1 \mathrm{H}, \mathrm{C}-4$ thiazole ring), $10.10(\mathrm{~s}, 1 \mathrm{H}$, NH-benzimidazole ring). ${ }^{13} \mathrm{C}-\mathrm{NMR}: \delta / \mathrm{ppm}=43.3,107.8,115.2(2 \mathrm{C}), 123.0(2 \mathrm{C}), 127.5,128.4(2 \mathrm{C}), 134.8$ (2C), 136.3, $138.8(2 \mathrm{C}), 141.5,158.2,161.3$. MS $(m / z, \%): 306\left(\mathrm{M}^{+}, 18.4\right)$. HRMS calc. for $\mathrm{C}_{17} \mathrm{H}_{14} \mathrm{~N}_{4} \mathrm{~S}$ : 306.0939, found: 306.0960 .

\subsubsection{General Procedure for the Synthesis of the Arylazo Derivatives $(7 \mathbf{a}-\mathbf{c})$ and $(\mathbf{8 a}-\mathbf{c})$}

The corresponding aryl diazonium chlorideswere prepared by adding cold sodium nitrite solution $0.69 \mathrm{~g}, 10 \mathrm{mmol}$ in $15 \mathrm{~mL}$ of $\mathrm{H}_{2} \mathrm{O}$ ) to a cold suspension of different aromatic amines $(10 \mathrm{mmol})$ in concentrated $\mathrm{HCl}(4-6 \mathrm{~mL})$ with continuous stirring. To a cold solution of (2-((1H-benzimidazol-2-yl)methyl)amino)thiazo-4(5H)-one 5 (2.46 g,10 mmol) and/or $\mathrm{N}-((1 \mathrm{H}$ benzimidazol-2-yl)methyl)-4-phenylthiazol-2-amine6(3.06 g, $10 \mathrm{mmol})$ in ethanol $(20 \mathrm{~mL})$ and sodium acetate $(1.6 \mathrm{~g}, 20 \mathrm{mmol})$, a cold aqueous solution from the corresponding aromatic diazonium salts were added dropwise with stirring at $0-5{ }^{\circ} \mathrm{C}$ for two $\mathrm{h}$. The solid products obtained were filtered off, washed with water followed by cold ethanol, dried, and recrystallized from 
ethanol to give 2-((1H-benzimidazol-2-yl)methyl)imino)-5-(2-aryldiazenyl)thiazolidin-4-one (7a-c) and $\mathrm{N}$-((1H-benzimidazol-2-yl)methyl)-5-(aryldiazenyl)-4-phenylthiazol-2(3H)-imine (8a-c).

2-(((1H-benzimidazol-2-yl)methyl)amino)-5-((4-nitrophenyl)diazenyl)thiazol-4(5H)-one (7a). Dark brown solid; M.p.: $>250{ }^{\circ} \mathrm{C}$, Yield: $2.9 \mathrm{~g}, 73 \%$. IR: $v_{\max }=3366-2961(\mathrm{NH},=\mathrm{CH}$ aromatic, $-\mathrm{CH}$ aliphatic), $1635(\mathrm{CO}), 1585(\mathrm{C}=\mathrm{N}), 1438\left(\mathrm{CH}_{2}\right)$ and 1332, $1519\left(\mathrm{NO}_{2}\right) \mathrm{cm}^{-1} .{ }^{1} \mathrm{H}-\mathrm{NMR}: \delta / \mathrm{ppm}=2.50\left(\mathrm{~s}, 2 \mathrm{H}, \mathrm{CH}_{2}\right.$ aliphatic), $4.11(\mathrm{~s}, 1 \mathrm{H}, \mathrm{NH}), 7.18-7.89(\mathrm{~m}, 8 \mathrm{H}, \mathrm{Ar}-\mathrm{H}), 9.70\left(\mathrm{~s}, 1 \mathrm{H}, \mathrm{NH}\right.$-benzimidazole ring). ${ }^{13} \mathrm{C}-\mathrm{NMR}$ : $\delta / \mathrm{ppm}=43.5,74.6,115.2(2 \mathrm{C}), 120.5(2 \mathrm{C}), 123.0(2 \mathrm{C}), 124.1(2 \mathrm{C}), 138.8(2 \mathrm{C}), 141.5,157.4,157.0,158.2$, 173.3. MS $(m / z, \%): 395\left(\mathrm{M}^{+}, 0.45\right)$. HRMS calc. for $\mathrm{C}_{17} \mathrm{H}_{13} \mathrm{~N}_{7} \mathrm{O}_{3} \mathrm{~S}: 395.0801$, found: 395.0822 .

2-(((1H-benzimidazol-2-yl)methyl)amino)-5-(p-tolyldiazenyl)thiazol-4(5H)-one (7b). Dark brown solid; M.p.: $>250{ }^{\circ} \mathrm{C}$, Yield: $1.9 \mathrm{~g}, 53 \%$. IR: $v_{\max }=3627-2799(\mathrm{NH},=\mathrm{CH}$ aromatic, $-\mathrm{CH}$ aliphatic), $1654(\mathrm{CO})$, $1595(\mathrm{C}=\mathrm{N}), 1441\left(\mathrm{CH}_{2}\right)$ and1408 $\left(\mathrm{CH}_{3}\right) \mathrm{cm}^{-1} .{ }^{1} \mathrm{H}-\mathrm{NMR}: \delta / \mathrm{ppm}=2.50\left(\mathrm{~s}, 3 \mathrm{H}, \mathrm{CH}_{3}\right), 3.08(\mathrm{~s}, 2 \mathrm{H}$, $\mathrm{CH}_{2}$ aliphatic), $4.89(\mathrm{~s}, 1 \mathrm{H}, \mathrm{NH}), 7.21-8.48(\mathrm{~m}, 8 \mathrm{H}, \mathrm{Ar}-\mathrm{H})$ and $8.91(\mathrm{~s}, 1 \mathrm{H}, \mathrm{NH}$-benzimidazole ring). ${ }^{13} \mathrm{C}-\mathrm{NMR}: \delta / \mathrm{ppm}=21.3,43.7,74.6,115.2(2 \mathrm{C}), 122.5(2 \mathrm{C}), 123.0(2 \mathrm{C}), 129.1(2 \mathrm{C}), 138.8(2 \mathrm{C}), 141.5$, 147.7, 157.7, 158.2, 173.4. MS ( $m / z, \%): 364\left(\mathrm{M}^{+}, 0.18\right)$. HRMS calc. for $\mathrm{C}_{18} \mathrm{H}_{168} \mathrm{~N}_{6} \mathrm{OS}: 364.1106$, found: 364.1131 .

2-(((1H-benzimidazol-2-yl)methyl)amino)-5-((4-acetylphenyl)diazenyl)thiazol-4(5H)-one (7c). Brown solid; M.p.: $>250{ }^{\circ} \mathrm{C}$, Yield: $1.9 \mathrm{~g}, 49 \%$. IR: $v_{\max }=3627-2990(\mathrm{NH},=\mathrm{CH}$ aromatic, $-\mathrm{CH}$ aliphatic), 1660 (CO), $1591(\mathrm{C}=\mathrm{N}), 1431\left(\mathrm{CH}_{2}\right)$ and $1402\left(\mathrm{CH}_{3}\right) \mathrm{cm}^{-1} .{ }^{1} \mathrm{H}-\mathrm{NMR}: \delta / \mathrm{ppm}=2.49\left(\mathrm{~s}, 3 \mathrm{H}, \mathrm{CH}_{3}\right), 3.32(\mathrm{~s}, 2 \mathrm{H}$, $\mathrm{CH}_{2}$ aliphatic), $4.11(\mathrm{~s}, 1 \mathrm{H}, \mathrm{NH}), 7.16-7.98(\mathrm{~m}, 8 \mathrm{H}, \mathrm{Ar}-\mathrm{H})$ and $9.54(\mathrm{~s}, 1 \mathrm{H}, \mathrm{NH}$-benzimidazole ring). ${ }^{13} \mathrm{C}-\mathrm{NMR}: \delta / \mathrm{ppm}=26.4,43.7,74.6,115.2(2 \mathrm{C}), 122.5(2 \mathrm{C}), 123.0(2 \mathrm{C}), 129.1(2 \mathrm{C}), 133.6,138.8(2 \mathrm{C}), 141.5$, 155.1, 158.2, 173.3, 197.0. MS ( $m / z, \%): 393.11\left(\mathrm{M}^{+}, 20.5\right)$. HRMS calc. for $\mathrm{C}_{19} \mathrm{H}_{15} \mathrm{~N}_{6} \mathrm{O}_{2} \mathrm{~S}: 392.1055$, found: 392.1071 .

N-((1H-benzimidazol-2-yl)methyl)-5-((4-nitrophenyl)diazenyl)-4-phenylthiazol-2-amine (8a). Brown solid; M.p.: $183-185{ }^{\circ} \mathrm{C}$, Yield: $3.2 \mathrm{~g}, 72 \%$. IR: $v_{\max }=3366-2950(\mathrm{NH},=\mathrm{CH}$ aromatic, $-\mathrm{CH}$ aliphatic), 1629 $(\mathrm{C}=\mathrm{N}), 1444\left(\mathrm{CH}_{2}\right)$ and 1322, $1513\left(\mathrm{NO}_{2}\right) \mathrm{cm}^{-1} .{ }^{1} \mathrm{H}-\mathrm{NMR}: \delta / \mathrm{ppm}=2.50\left(\mathrm{~s}, 2 \mathrm{H}, \mathrm{CH}_{2}\right.$ aliphatic), 5.32 $(\mathrm{s}, 1 \mathrm{H}, \mathrm{NH}), 7.52-8.31(\mathrm{~m}, 13 \mathrm{H}, \mathrm{Ar}-\mathrm{H}), 8.99\left(\mathrm{~s}, 1 \mathrm{H}, \mathrm{NH}-\right.$ benzimidazole ring). ${ }^{13} \mathrm{C}-\mathrm{NMR}: \delta / \mathrm{ppm}=$ 44.2, 89.6, $115.2(2 \mathrm{C}), 123.0(2 \mathrm{C}), 123.8(2 \mathrm{C}), 126.5(2 \mathrm{C}), 127.9,128.3(2 \mathrm{C}), 128.6(2 \mathrm{C}), 134.1,138.8(2 \mathrm{C})$, 141.5, 147.8, 154.1, 158.2, 161.0. MS ( $m / z, \%): 455\left(\mathrm{M}^{+}, 24.9\right)$. HRMS calc. for $\mathrm{C}_{23} \mathrm{H}_{17} \mathrm{~N}_{7} \mathrm{O}_{2} \mathrm{~S}: 455.1164$, found: 455.1145 .

N-((1H-benzimidazol-2-yl)methyl)-4-phenyl-5-(p-tolyldiazenyl)thiazol-2-amine (8b). Brown solid; M.p.: $162-163{ }^{\circ} \mathrm{C}$, Yield $4 \mathrm{~g}, 95 \%$. IR: $v_{\max }=3385-2964(\mathrm{NH},=\mathrm{CH}$ aromatic, $-\mathrm{CH}$ aliphatic $), 1636(\mathrm{C}=\mathrm{N}), 1475$ $\left(\mathrm{CH}_{2}\right)$, and $1407\left(\mathrm{CH}_{3}\right) \mathrm{cm}^{-1} .{ }^{1} \mathrm{H}-\mathrm{NMR}: \delta / \mathrm{ppm}=2.25\left(\mathrm{~s}, 3 \mathrm{H}, \mathrm{CH}_{3}\right), 3.44\left(\mathrm{~s}, 2 \mathrm{H}, \mathrm{CH}_{2}\right.$ aliphatic), 4.22 $(\mathrm{s}, 1 \mathrm{H}, \mathrm{NH}), 7.09-7.57(\mathrm{~m}, 13 \mathrm{H}, \mathrm{Ar}-\mathrm{H}), 10.14\left(\mathrm{~s}, 1 \mathrm{H}, \mathrm{NH}\right.$-benzimidazole ring). ${ }^{13} \mathrm{C}-\mathrm{NMR}: \delta / \mathrm{ppm}=$ 21.3, 44.2, 89.6, 115.2 (2C), 123.0 (2C), 127.8, 128.3 (2C), 128.6 (2C), 128.7 (2C), 129.0 (2C), 134.1, 138.4, $138.8(2 \mathrm{C}), 141.5,145.1,158.2,161.0$. MS ( $m / z, \%): 424\left(\mathrm{M}^{+}, 1.36\right)$. HRMS calc. for $\mathrm{C}_{24} \mathrm{H}_{20} \mathrm{~N}_{6} \mathrm{~S}: 424.1470$, found: 424.1452 .

1-(4-((2-(((1H-benzimidazol-2-yl)methyl)amino)-4-phenylthiazol-5-yl)diazenyl)phenyl)ethan-1-one (8c).Brown solid; M.p.: $130-131{ }^{\circ} \mathrm{C}$, Yield: $4.3 \mathrm{~g}, 96 \%$. IR: $v_{\max }=3295-2855(\mathrm{NH},=\mathrm{CH}$ aromatic, $-\mathrm{CH}$ aliphatic), $1656\left(\mathrm{CO}\right.$ acetyl), $1588(\mathrm{C}=\mathrm{N}), 1474\left(\mathrm{CH}_{2}\right)$, and $1407\left(\mathrm{CH}_{3}\right) \mathrm{cm}^{-1} .{ }^{1} \mathrm{H}-\mathrm{NMR}: \delta / \mathrm{ppm}=2.54(\mathrm{~s}, 3 \mathrm{H}$, $\left.\mathrm{CH}_{3}\right), 3.43\left(\mathrm{~s}, 2 \mathrm{H}, \mathrm{CH}_{2}\right.$ aliphatic), $4.32(\mathrm{~s}, 1 \mathrm{H}, \mathrm{NH}), 7.31-8.43(\mathrm{~m}, 13 \mathrm{H}, \mathrm{Ar}-\mathrm{H})$ and $10.94(\mathrm{~s}, 1 \mathrm{H}$, $\mathrm{NH}$-benzimidazole ring). ${ }^{13} \mathrm{C}-\mathrm{NMR}: \delta / \mathrm{ppm}=26.4,44.2,89.6,115.2(2 \mathrm{C}), 123.0(2 \mathrm{C}), 128.3(2 \mathrm{C}), 128.6$ (5C), 128.7 (2C), 134.1, 136.4, 138.8 (2C), 141.5, 152.2, 158.2, 161.0, 197.0. MS ( $m / z, \%): 452\left(\mathrm{M}^{+}, 0.23\right)$. HRMS calc. for $\mathrm{C}_{25} \mathrm{H}_{20} \mathrm{~N}_{6} \mathrm{OS}: 452.1419$, found: 452.1423 . 


\section{Conclusions}

In the development of this work, the newly synthesized series of benzimidazole derivatives $\mathbf{3 a - c}$, $\mathbf{7 a - c}$, and 8a-c derived from 2-(bromomethyl)- $1 H$-benzimidazole were prepared in satisfactory yields and fully characterized. They exhibited in vitro variable antimicrobial activities when subjected to the bacterial strains Staphylococcus aureus (Gram-positive bacteria) and Escherichia coli (Gram-negative bacteria) compared with Kanamycin and Ampicillin as standard drugs, respectively. Their inhibition effect against DPPH (the lowest $\mathrm{EC}_{50}$ values) compared to Trolox $\left(\mathrm{EC}_{50}=55.13\right)$ was shown as well. They were screened for their antitumor activities against human liver cancer cell line (HepG2) to evaluate the cytotoxic effects of gradient concentrations $(100-500 \mu \mathrm{g} / \mathrm{mL})$ in terms of cell viability percentage and $\mathrm{EC}_{50}$ values. The tested compounds exhibited noticeable efficiency against the tumor cell line under investigation at the higher concentration. The benzimidazole derivatives $(\mathbf{3 a}, \mathbf{c})$ and $(\mathbf{8 b})$ showed higher activity than the other selected compounds that were tested. Presence of electron withdrawing groups increased the antitumor activities as discussed.

Author Contributions: M.E.K., A.A.G., F.M.K., T.A.T. and A.S.A.M. conceived, designed the experiments, performed the experiments, analyzed the data, contributed reagents/materials/analysis tools and wrote the paper. M.A.M. designed, supervised and performed the biological experiments.

Funding: This work was funded by the King Abdulaziz City for Science and Technology (KACST)-Saudi Arabia (project No. 1-17-01-022-0006). The Authors acknowledge support from the Scientific Research Unit of Taif University, Saudi Arabia.

Conflicts of Interest: The authors declare no conflict of interest. The founding sponsors had no role in the design of the study; in the collection, analyses, or interpretation of data; in the writing of the manuscript, and in the decision to publish the results.

\section{References}

1. Woolley, D. Some biological effects produced by benzimidazole and their reversal by purines. J. Biol. Chem. 1944, 152, 225-232.

2. Khalifa, M.E.; Gobouri, A.A. Benzimdazoles Classics and Advances; Lambert Academic Publishing: Saarbrücken, Germany, 2018; p. 118.

3. Shukla, A. Synthesis and biological screening of benzimidazole derivatives. Int. J. Pharm. Sci. Res. 2012, 3 , 922. [CrossRef]

4. Tupe, A.; Pawar, P.; Mane, B.; Magar, S. Synthesis analgesic and anti-inflammatory activity of some 2-substituted 3-acetic acid benzimidazole derivatives. Res. J. Pharm. Biol. Chem. Sci. 2013, 4, 928-935.

5. Cashin, C.H.; Dawson, W.; Kitchen, E.A. The pharmacology of benoxaprofen (2-[4-chlorophenyl]- $\alpha$ methyl-5-benzoxazole acetic acid), LRCL 3794, a new compound with anti-inflammatory activity apparently unrelated to inhibition of prostaglandin synthesis. J. Pharm. Pharmacol. 1977, 29, 330-336. [CrossRef] [PubMed]

6. Singh, S.P.; Parmar, S.S.; Raman, K.; Stenberg, V.I. Chemistry and biological activity of thiazolidinones. Chem. Rev. 1981, 81, 175-203. [CrossRef]

7. Mariappan, G.; Bhuyan, N.; Kumar, P.; Kumar, D.; Murali, K. Synthesis and biological evaluation of Mannich bases of benzimidazole derivatives. Indian J. Chem. 2011, 50, 1216-1219.

8. Ansari, K.F.; Lal, C. Synthesis and biological activity of some heterocyclic compounds containing benzimidazole and beta-lactam moiety. J. Chem. Sci. 2009, 121, 1017-1025. [CrossRef]

9. Al-Ebaisat, H.S. Synthesis and Biological Activities of Some Benzimidazoles Derivatives. J. Appl. Sci. Environ. 2011, 15, 451-454.

10. Kankate, R.S.; Gide, P.S.; Belsare, D.P. Design, synthesis and antifungal evaluation of novel benzimidazole tertiary amine type of fluconazole analogues. Arab. J. Chem. 2015, in press. [CrossRef]

11. Chimirri, A.; Grasso, S.; Monforte, P.; Rao, A.; Zappala, M.; Monforte, A.; Pannecouque, C.; Witvrouw, M.; Balzarini, J.; De Clercq, E. Synthesis and biological activity of novel $1 \mathrm{H}, 3 \mathrm{H}$-thiazolo [3- $a$ ] benzimidazoles: Non-nucleoside human immunodeficiency virus type 1 reverse transcriptase inhibitors. Antivir. Chem. Chemother. 1999, 10, 211-217. [CrossRef] 
12. Shinegare, M.; Mane, D.; Shinde, D.; Thore, S.; Bhawsar, S. Synthesis of Mannich Bases of Benzimidazole as Possible Antiviral Agents. Asian J. Chem. 1996, 8, 225-228.

13. Kagthara, P.; Upadhyay, T.; Doshi, R.; Parekh, H. Synthesis of some 2-azetidinones as potential antitubercular agents. Indian J. Heterocycl. Chem. 2000, 10, 9-12.

14. Kumar, K.; Awasthi, D.; Lee, S.Y.; Zanardi, I.; Ruzsicska, B.; Knudson, S.; Ojima, I. Novel trisubstituted benzimidazoles, targeting Mtb FtsZ, as a new class of antitubercular agents. J. Med. Chem. 2010, 54, 374-381. [CrossRef] [PubMed]

15. Sreena, K.; Ratheesh, R.; Rachana, M.; Poornima, M.; Shyni, C. Synthesis and anthelmintic activity of benzimidazole derivatives. Hygeia 2009, 1, 21-22.

16. McKellar, Q.A.; Scott, E.W. The benzimidazole anthelmintic agents-a review. J. Vet. Pharmacol. Ther. 1990, 13, 223-247. [CrossRef] [PubMed]

17. Rossignol, J.F.; Maisonneuve, H. Benzimidazoles in the treatment of trichuriasis: A review. Ann. Trop. Med. Parasitol. 1984, 78, 135-144. [CrossRef]

18. Dubey, A.; Sanyal, P. Benzimidazoles in a wormy world. Online Vet. J. 2010, 5, 63-66.

19. Walia, R.; Hedaitullah, M.; Naaz, S.F.; Iqbal, K.; Lamba, H. Benzimidazole derivatives-an overview. Int. J. Res. Pharm. Chem. 2011, 1, 565-574.

20. Çakir, B.; Yildirim, E.; Ercanli, T.; Erol, K.; Sahin, M.F. Synthesis and anticonvulsant activity of some (2/4-substituted)benzaldehyde (2-oxobenzothiazolin-3-yl)acetohydrazones. Il Farm. 1999, 54, 842-845. [CrossRef]

21. Kalyankar, T.; Pekamwar, S.; Wadher, S.; Tiprale, P.; Shinde, G. Review on benzimidazole derivative. Int. J. Chem. Pharm. Sci. 2012, 3, 1-10.

22. Kapuriya, K.; Ganure, A.; Davda, S.; Kitawala, M.; Topiya, H. Benzimidazole: A promising lead for anticancer drug design. Univ. J. Pharm. 2013, 2, 57-62.

23. Nare, B.; Liu, Z.; Prichard, R.K.; Georges, E. Benzimidazoles, potent anti-mitotic drugs: Substrates for the P-glycoprotein transporter in multidrug-resistant cells. Biochem. Pharmacol. 1994, 48, 2215-2222. [CrossRef]

24. Patil, A.; Ganguly, S.; Surana, S. A systematic review of benzimidazole derivatives as an antiulcer agent. Rasayan J. Chem. 2008, 1, 447-460.

25. Patil, A.; Ganguly, S.; Surana, S. Synthesis and antiulcer activity of 2-[5-substituted-1-H-benzo (d) imidazol-2-yl sulfinyl] methyl-3-substituted quinazoline-4-(3H) ones. J. Chem. Sci. 2010, 122, 443-450. [CrossRef]

26. Kohara, Y.; Kubo, K.; Imamiya, E.; Wada, T.; Inada, Y.; Naka, T. Synthesis and Angiotensin II Receptor Antagonistic Activities of Benzimidazole Derivatives Bearing Acidic Heterocycles as Novel Tetrazole Bioisosteres 1. J. Med. Chem. 1996, 39, 5228-5235. [CrossRef] [PubMed]

27. Reddy, B.A. Synthesis and Characterization of Some Benzimidazole Derivatives using as anti-hypertensive Agents. Asian J. Pharm. Res. Health Care 2010, 2. [CrossRef]

28. Spasov, A.; Yozhitsa, I.; Bugaeva, L.; Anisimova, V. Benzimidazole derivatives: Spectrum of pharmacological activity and toxicological properties (a review). Pharm. Chem. J. 1999, 33, 232-243. [CrossRef]

29. Boiani, M.; González, M. Imidazole and benzimidazole derivatives as chemotherapeutic agents. Mini-Rev. Med. Chem. 2005, 5, 409-424. [CrossRef]

30. Narasimhan, B.; Sharma, D.; Kumar, P. Benzimidazole: A medicinally important heterocyclic moiety. Med. Chem. Res. 2012, 21, 269-283. [CrossRef]

31. Goswami, B.; Singh, A.K. Pharmacological activities of benzimidazole derivatives-Overview. IJSID 2012, 2, 121-136.

32. Manna, K.; Agrawal, Y.K. Microwave assisted synthesis of new indophenazine 1, 3, 5-trisubstruted pyrazoline derivatives of benzofuran and their antimicrobial activity. Bioorg. Med. Chem. Lett. 2009, 19, 2688-2692. [CrossRef] [PubMed]

33. Abdel-Latif, E.; Amer, F.; Metwally, M.; Khalifa, M. Synthesis of 5-arylazo-2-(arylidenehydrazino)-thiazole disperse dyes for dyeing polyester fibres. Pigment Resin Technol. 2009, 38, 105-110. [CrossRef]

34. Gaffer, H.E.; Fouda, M.M.; Khalifa, M.E. Synthesis of some novel 2-amino-5-arylazothiazole disperse dyes for dyeing polyester fabrics and their antimicrobial activity. Molecules 2016, 21, 122. [CrossRef] [PubMed]

35. Khalifa, M.; Abdel-Latif, E.; Gobouri, A. Disperse Dyes Based on 5-Arylazo-thiazol-2-ylcarbamoylthiophenes: Synthesis, Antimicrobial Activity and Their Application on Polyester. J. Heterocycl. Chem. 2015, 52, 674-680. [CrossRef] 
36. Khalifa, M.E. Recent Developments and Biological Activities of 2-Aminothiazole Derivatives. Acta Chim. Slov. 2018, 65, 1-22. [CrossRef] [PubMed]

37. Khalifa, M.E.; Abdel-Hafez, S.H.; Gobouri, A.A.; Kobeasy, M.I. Synthesis and biological activity of novel arylazothiazole disperse dyes containing selenium for dyeing polyester fibers. Phosphorus Sulfur Silicon Relat. Elem. 2015, 190, 461-476. [CrossRef]

38. Khalifa, M.E.; Abdel-Latif, E.; Amer, F.A.; Metwally, M.A. Synthesis of some new 5-arylazothiazole derivatives as disperse dyes for dyeing polyester fibers. Int. J. Text. Sci. 2012, 1, 62-68. [CrossRef]

39. Khalifa, M.E.; Metwally, M.A.; Abdel-latif, E.; Amer, F.A. New Azo Heterocyclic Disperse Dyes with Thiophene Moiety for Dyeing Polyester Fibers. Int. J. Text. Sci. 2012, 1, 1-6.

40. Khalifa, M.E.; Mohamed, M.A.-H.; Alshehri, N.H. Synthesis of novel 2-amino-5-arylazothiazol derivatives and their biological impacts: Assessment of toxicity and antioxidant enzymes activities. Maced. J. Chem. Chem. Eng. 2015, 34, 309-319. [CrossRef]

41. Khalifa, M.E.; Elkhawass, E.A.; Pardede, A.; Ninomiya, M.; Tanaka, K.; Koketsu, M. A facile synthesis of formazan dyes conjugated with plasmonic nanoparticles as photosensitizers in photodynamic therapy against leukemia cell line. Monatsh. Chem. 2018, 149, 2195-2206. [CrossRef]

42. Bhatt, A.; Sanghvi, V.; Parmar, M.; Shah, P.; Karadia, H.; Patel, H. Synthesis and biological activities of some 4-thiazolidinones derivatives. Orient. J. Chem. 2003, 19, 473-476.

43. Mahalakshmi, C.; Chidambaranathan, V. Synthesis, spectral characterization and antimicrobial studies of novel benzimidazole derivatives. Int. J. Chem. Sci. 2015, 13, 205-212.

44. Speziale, A.J. Ethanedithiol-1, 2-Ethanedithiol. Org. Synth. 1950, 30, 35-37.

45. Tiden, A.; Viklund, J. Preparation of Thioxanthines as Inhibitors of Myeloperoxidase (MPO). Available online: https:/ / patentscope.wipo.int/search/en/detail.jsf?docId=WO2007120098 (accessed on 8 November 2018).

46. Sujayev, A.; PolatKose, L.; Garibov, E.; Gülçin, İ.; Farzaliev, V.; Alwasel, S.H.; Supuran, C.T. Synthesis of N-alkyl (aril)-tetra pyrimidine thiones and investigation of their human carbonic anhydrase I and II inhibitory effects. J. Enzyme Inhib. Med. Chem. 2016, 31, 1192-1197. [CrossRef]

47. Alkan, C.; Tek, Y.; Kahraman, D. Preparation and characterization of a series of thiourea derivatives as phase change materials for thermal energy storage. Turk. J. Chem. 2011, 35, 769-777.

48. Srinivas, B.; Priya, V.R.; Babu, G.S.; Rao, J.V.; Malathy, P.; Manohar, K.R.; Prakash, B.C.; Srikanth, L. Synthesis and Screening of New Isatin Derivatives. Pharma Chem. 2010, 2, 378-384.

49. Yamamoto, Y.; Togawa, Y.; Shimosaka, M.; Okazaki, M. Purification and characterization of a novel bacteriocin produced by Enterococcus faecalis strain RJ-11. Appl. Environ. Microbiol. 2003, 69, 5746-5753. [CrossRef]

50. Nagai, T.; Inoue, R.; Suzuki, N.; Myoda, T.; Nagashima, T. Antioxidative ability in a linoleic acid oxidation system and scavenging abilities against active oxygen species of enzymatic hydrolysates from pollen Cistus ladaniferus. Int. J. Mol. Med. 2005, 15, 259-263. [CrossRef]

51. Sztaricskai, F.; Takács, I.E.; Pusztai, F.; Szabó, G.; Csípõ, I. Antiulcer Effect of the N-and O- $\beta$-D-Glucopyranosides of 5-Aminosalicylic Acid. Arch. Pharm. 1999, 332, 321-326. [CrossRef]

52. Repetto, G.; del Peso, A.; Zurita, J.L. Neutral red uptake assay for the estimation of cell viability/cytotoxicity. Nat. Protoc. 2008, 3, 1125-1131. [CrossRef]

53. Shanab, S.M.M.; Shalaby, E.A.; El Fayoumy, E.A. Enteromorpha compressa Exhibits Potent Antioxidant Activity. J. Biomed. Biotechnol. 2011, 2011, 1-11. [CrossRef] [PubMed]

54. Nie, N.H.; Bent, D.H.; Hull, C.H. SPSS: Statistical Package for the Social Sciences; MacGraw-Hill: New York, NY, USA, 1975.

55. Fautz, R.; Husein, B.; Hechenberger, C. Application of the neutral red assay (NR assay) to monolayer cultures of primary hepatocytes: Rapid colorimetric viability determination for the unscheduled DNA synthesis test (UDS). Mutat. Res. Environ. Mutagen. 1991, 253, 173-179. [CrossRef]

56. Brand-Williams, W.; Cuvelier, M.E.; Berset, C. Use of a free radical method to evaluate antioxidant activity. LWT-Food Sci. Technol. 1995, 28, 25-30. [CrossRef]

57. Mariappan, G.; Hazarika, R.; Alam, F.; Karki, R.; Patangia, U.; Nath, S. Synthesis and biological evaluation of 2-substituted benzimidazole derivatives. Arab. J. Chem. 2015, 8, 715-719. [CrossRef] 
58. Alasmary, F.A.; Snelling, A.M.; Zain, M.E.; Alafeefy, A.M.; Awaad, A.S.; Karodia, N. Synthesis and evaluation of selected benzimidazole derivatives as potential antimicrobial agents. Molecules 2015, 20, 15206-15223. [CrossRef] [PubMed]

59. Mobinikhaledi, A.; Foroughifar, N.; Kalhor, M.; Mirabolfathy, M. Synthesis and antifungal activity of novel 2-benzimidazolylimino-5-arylidene-4-thiazolidinones. J. Heterocycl. Chem. 2010, 47, 77-80. [CrossRef]

Sample Availability: Samples of the compounds 3-8 are available from the authors.

(C) 2018 by the authors. Licensee MDPI, Basel, Switzerland. This article is an open access article distributed under the terms and conditions of the Creative Commons Attribution (CC BY) license (http://creativecommons.org/licenses/by/4.0/). 